\title{
Dilemma and Solution to Private Copy in Digital Technology
}

\author{
Sanjun Ma ${ }^{1, a}$, Yingwei Sun ${ }^{2, b}$ \\ 1 Hebei institute of engineering technology, Shijiazhuang,050091,China \\ ${ }^{2}$ Shijiazhuang University. Shijiazhuang,050035,china \\ achinajjj@126.com, b154207210@qq.com
}

Keywords: Private copy; Digital technology; Communication

\begin{abstract}
Private copy covers a progress from ignorance to abhorrence, which is mainly contributed by the advance of communication technology. Following the circumstance of digital technology, private copy leads to the change of main communication route. Circulators that earned a lot are forced to decrease interests now, but authors receive little from this change. Tech-measure is a kind of self protection for right owners. Laws compensate authors when the technology can be controlled.
\end{abstract}

\section{Introduction}

Private copy refers to that users copy in the private places for private purposes including any kind of copying for non-business purposes.[1] Private copy has existed for a long time when the books came out. Accounting to the print technique, private copy is merely blocked in handwriting and other costly solutions. Ergo, private copy is off responsibility for rational usage. But the development of technology accelerates the attitude to private copy by circulators. The call of enlarging private copy to copyright emerges rapidly after the invention of the Xerox machine and video cassette recorder. Especially after the digital technology, the trend to private copy has been clearer.

\section{The History of Private Copy}

Private copy in traditional technology. Publishing becomes profitable as a result of print technology advance, and copyright has been established gradually in special permission of publishing system. Publishing is the action about copying supplied works; copyright is a series of right cored by copy privilege. The initial copy privilege is within the commercial copy purpose; private copy is considered rational and is not controlled by owners of copyright.

The technology fundament abridged by traditional copyright system is printing. Because printing technology is seized by the enterprises with a large fund and rich power. The potential loss brought to owner of copyright is unauthoritative printing applied by limited numbers of enterprises. So it is simple and easy to look into these illegal operations. At the same time, private copy is only limited in handwriting and other inconvenient ways. The low speed and hard work determines handwriting as a way of copy is hard to expand due to the cost. The quality of handwritten copy cannot abreast the print version as well. Following this circumstance, private copy cannot compete with owner of copyright, and it does no harm to the interests of the owner of copyright. Ergo, private copy is off responsibility as the rational use, "Don't need to mention".[2] According to the text of the Berne Convention and the Rome Convention, private copy is regarded as rational use and is off the control by the owner of copy. This action is regarded to attain the balance among authors, publishers and 
readers, and combine the private interest with public interest.

Private copy after analog technology. After the emergence of xerography, private copy springed gradually, which influenced the market of works and endangered benefits of copyright owners. The technic advance of private copy which could be neglected initially hurts the right and benefit of copyright owner. Xerography had been paid high attention to. The planed documents made by Session of Government Specialist Committee for Print and Text organized by WIPO and UNESO in 1987 said, the privilege of authorizing copying his or her works enjoyed by author included xerography.

Different from xerography, video cassette recorder includes a pure issue about private copy carried by consumers individually. The emergence of video cassette recorder results in the rapid growing of private copy, which waves the control of copyright owner to copy. But facing enormous private copies and lawsuit difficulties, copyright owners blame the manufactures who supply consumers with video cassette recorder; copyright owners believe these manufactures assist infringement. The premise of infringement assistance is that private copy pirates the copyright from its owner, which means private copy is not within the range of rational use.

In June, 1984, Geneva. Specialist Session of WIPO/UNESCO( all member countries of the Berne Convention and Universal Copyright Convention attend this session) includes private copy into the copy privilege of copyright owner.The session approves that copy privilege not only covers the copy for public and profit, but also covers all kinds of copy for private purposes. Hereinafter, similar conclusion is found in relevant documents and sessions. Legislation and judicature both deny the legalism of private copy.

Private copy in digital technology. Digital technology is a science technology accompanying the birth of computer. It refers to applying certain equipment to convert kinds of information, including picture, text, sound, image, and so on, to binary code 0 and 1 , which can be collected by computer to calculate, process, store, deliver, communicate, and restore. The combination of digital technology and communication technology makes works much easily spread on the Internet, which causes the alert of the copyright owner. But what really concerns copyright owners, especially music copyright owner, is P2P.

Based on digital compression technology, $\mathrm{P} 2 \mathrm{P}$ is assembled by current digital technology such as search engine, instant messaging tool, document sharing software and so on. P2P makes users share digital music documents and copy any recorded music files conveniently from the Internet. Actually, other kinds of work can be copied like music. Especially the birth of the 4th generation of P2P technology causes users to share needed files freely. Even though web companies power off their own computers and controlled computers, users can still share files, which frees web supply company from infringement. The development of digital technology and cyber technology fills the gap between public use and private use. If private copy is out of control of copyright owner, copyright owner's interest may be in danger. In order to suppress the transmit of copyright works and maximize the interest in copyright, copyright owner must expand copyright to private copy in cyber space. So the record companies start to bring the suit to individuals.

Copy privilege is the core and fundament of copyright system, any communication is tightly connected with copy. Only controlling copy can realize the purpose of maximizing copyright benefits. Current copyright law also leaves space for the right expansion of copyright owners. According to the Berne Convention, the digitalization of works is in the range of copy. The occasional unavoidable copy in computer operating will even be included in the rights of copyright owners. We conduct that 
when technology steps, the right of copyright owner follows. Until today, the expansion of copyright reached to the peak.[3]

\section{Interest Conflict Analysis to Private Copy in Digital Technology}

Private copy's impact on the interest of the publisher. Most right owners, editors and some enterprises are all against setting exceptions for digital private copy. They think this sort of copy counters the legal use of works. Especially after the emergence of P2P, the audio record, video record, broadcasting record based on private purposes as well as the xerography of the prints, which accumulates to harm the copyright owner's interest. The interest here mainly refers to financial interest.

1. The convenient private copy in the digital technology changes the pattern of that seller monopolizes the selling. This cuts down the interests of vested interest groups.

Traditional selling pattern is controlled by publisher. The author is just a tool to make money for the publisher. The spread of work, just form author to consumer, must be in the controlled range of the publisher. The advance of technology partly collapses the selling chain which is made by the publisher. We could conclude the action like works spreading on the Internet and the increase of private copy initially influences the interest of certain groups which control the works' selling pattern. These groups include publisher, recorder maker, radio station and television station.

Private copy and communication has little impact on the interest of author and actor. America singer Janes Ian said, "Most singers are not victims, they are rewarded."[4] As for most copyright is not occupied by author, but seized by company. In the period of commercializing copyright, the author barely enjoy the copyright and they only get little payment.[5] In the point of new economy, private copy is not a pure battle between the consumers and monopoly organization, rather than assembles a battle between the new commercial pattern and old commercial pattern.

2. The applied digital technology and widespread of the Internet makes author become the center of copyright system.

With the help of the Internet, author can decide the publish issue dependently, which gets rid of the restrictions from the media monopolizer. Author becomes the core of the copyright system. Cyber not only deprives the record company's privilege for artistic celebrities, but also offers the stage for the grassroots, like many web singers, to perform without relying on the publishers. "When artists have another choice to arrange works with consumers, they may decide not to be involved in the selling pattern, which benefits few merchants, to sell own copyright in certain amount of money."

The significance of private copy in digital technology. Internet technology should not only be regarded as the tool which is used to pirate copyright. In reality, whatever we called technology and laws, adding technology plus laws, copyright owners cannot guarantee income form every corner of copyright applying.

1. In some meaning, private copy accelerates the spread of works and the advance of social.

The first function of setting copyright is promoting the advance of science and culture, the private copy based on rational ruler is one of measures to promote the co-advance in society. The spirit of establishing Internet is "sharing and communicating"; the habit of net-users is downloading for free and sharing. The digital technology has been developing. Facing the billions of copyright pirates, copyright owner cannot find a branch to take the responsibility of bringing a lawsuit against individuals who pirate copyright. But apparently this solution is not the key to the problem. Not only form the common creeds but also from the final target of copyright laws, people need to persuade the 
free flow and communication of information.

2. Copyright is the need of developing digital technology and newly developing industries.

Internet has changed our lifestyle, at the same time, promoting the deep and lasting adjustment to the industrial structure. The development of the technology will deprive publisher of the limit of paper and print in some degree. That publisher upgrades to the base of digital technology and Internet is the trend. We must acknowledge this new industry. Traditional press needs to keep the pace, take belonging advantages in the adjustment of industry and seize the opportunity carried by the industry adjustment, rather than only insists on the copyright concept to depress the new developing industry.

3. Private copy increases the new way of using the works, which can benefit copyright owner more.

What the digital technology brings to copyright owner is not only risk but also opportunity. That the spread of works makes the new applying pattern possible. The new applying pattern increases the possibility of profiting.

The invention of radio worried record companies much, but later that radio invited more music into people's life profited the record companies; video cassette recorder was once regarded as an enemy by movie firms, but what had been proved that the wide spread of video cassette recorder accelerated the rent and selling market of movies, and the initial enemy became the new profit point; the establishment of public library tolled the bell for publishers, but in the end public library created the new commercial pattern for popular books publishing, and this pattern bought more opportunities for publishers. "In reality, some presses, like Massachusetts Institute of Technology Press and National Academies Press, upload the whole book text to the Internet for readers to browse and download, which is as the sale pattern of selling the hard copies. These presses reach their goals: the selling number of these hard copies increases rapidly."[6]

\section{Solution to Private Copy in Digital Technology}

The technique advance is the reason why private copy multiples, at the same time, technique protection measure is the anecdotic to solve the issue of private copy. The technique advance effectively controls the private copy, which makes payment clear. However, we must acknowledge the technique measures, especially the measures of access control, may block the technology advance and industry development. The measure will lead to irrational information monopolization. Because it may limit the consumers' rational use or legally authorized use.

In the issue of digital work's copyright protection, laws operate the adjustment function. To the money sharing issue among the selling branches after the appearance of new technology, the method like compensation for record store device, tape recorder and similar electronic devices can be followed. Certain amount of compensation can be paid to keep balance of software and hardware between MP3 and P2P. The benefit balance can be reached among right owners, technology engineers and consumers.

The competition between new business pattern and old business pattern originated from the market had better be solved by market. The benefits among telecom operator, network operator and digital work originator are adjusted by contract. With applying market rules, establishing commercial pattern which can guarantee win-win and wins, leading participants to enlarge the market and rising the profitable space, the benefits of participants will obtain balance. For example, based on the technology, selling devices (iPod), selling music record, purchasing certain music in the certain store 
and playing on certain device can become some patterns. We must emphasize the alert about over-protection for copyright,in order not to block the development of new industry pattern and new commercial pattern.

\section{Bibliography (References)}

[1]Fetscher, The Law of Copyright and The Internet[M], translated by S.K.Guo, Encyclopedia of China Publishing House, Beijing, 2008, pp. 498-499.

[2]J.X.Yi, Technology Development and the Expansion of Copyright[M](In Chinese), Law Press.China, Beijing, 2009, pp.134-135.

[3]Goldstein, From Gutenberg to the Celestial Jukebox[M], translated by H.J.Jin, Peking University Press, Beijing, 2008, pp. 166-168.

[4]Janis Ian, The Internet Debacle:An Alternative View[M]. Reference: Fischer, Promises to Keep:Technology, Law, and the Future of Entertainment[M]. Translated by X.Li, SDX Joint Publishing Company, Shanghai, 2008, pp. 25-26.

[5]Drahos, Information Feudalism[M], Translated by X.T.Liu, Intellectual Property Publishing House Co.,Ltd, Beijing, 2009, pp.15-17.

[6]Committee on Intellectual Property Rights and the Emerging Information Infrastructure, The Digital Dilemma: Intellectual Property in the Information Age, The National Academy Press, 2000, p.182. Reference: J.X.Yi, Technology Development and the Expansion of Copyright[M]. Law Press· China, Beijing, 2009., pp. 212-213. 